\title{
Setting Interval Time for Changing Critical Components of JRC JMA 5310 Radar using FMECA Method: A Case Study in KOARMATIM Patrol Ship Unit
}

\author{
Marsetio $^{1}$, Amarulla Octavian ${ }^{1}$, Ahmadi $^{2}$, Siswo Hadi Sumantri ${ }^{2}$, Rajab Ritonga ${ }^{3}$ \\ and Yusnaldi ${ }^{1}$ \\ ${ }^{1}$ Indonesia Defense University, Bogor, West Java, Indonesia \\ ${ }^{2}$ Sekolah Tinggi Angkatan Laut, Surabaya, East Java, Indonesia \\ ${ }^{3}$ Universitas Prof Dr Moestopo (Beragama), Jakarta, Indonesia \\ *Corresponding author: rajab.ritonga@dsn.moestopo.ac.id
}

\begin{abstract}
The application of navigation radar onboard a battleship, in particular in KOARMATIM Patrol Ship Unit, as a long range detecting device is notably vital. It is an absolute necessity for a battleship executing operation, so that the readiness of navigation radar will highly affect the execution of operational duties of those elements. Therefore, it will take a well planned maintenance management in repairing or eliminating failure to keep the system performance from falling. Failure Mode Effect and Criticality Analysis (FMECA) is the method used in identifying and analyzing all potential failure modes of various parts of the system, the effect of failure to the system, and how to avoid failure or reduce the impact of the failure to the system. This paper presents an application of FMECA model in defining critical component of JRC JMA 5310 Navigation Radar. This FMECA model generates Risk Priority Number (RPN) that will be used in defining critical components. The RPN value of each component is analyzed using Risk Matrix, which produces seven components regarded as critical out of twenty seven identified components, namely Modulator, Power Supply Scanner, Diode Limiter, Magnetron, Receiver, Motor, and Circulator. Modulator component has the highest RPN value of 24180 while Plotter Control Circuit component has the lowest RPN value of 3289. In setting the interval time for changing critical components, Reliability and Cost Benefit Ratio (CBR) approach is employed. The results show that Diode Limiter achieved the fastest changing time, namely 152 days, while the components with the longest changing time are Motor and Circulator with 458 days. The CBR value of all critical components are less than $1(C B R<1)$ which shows that the recommended changing cost is efficient. Diode Limiter component has the most efficient CBR value, namely 0.57572. The sensitivity analysis found that Reliability $R(t)$ variable has a big impact in alteration of defining critical component changing interval time, which supports $\beta$ (slope), $Y$ (location), and $\eta$ (scale) parameter. The $\beta$ parameter has more effect to alteration of Reliability $R(t)$ value.
\end{abstract}

Keywords: FMECA; Risk priority number; Reliability; Changing time interval; Cost benefit ratio

\section{Introduction}

The KOARMATIM (Eastern Fleet Command) patrol ship unit is the supervisory operating command with the main function of executing supervision of the combat force and skill of its organic elements in line with its basic function, namely in anti-surface ship and anti-air war field in order to improve the combat skill of the Indonesian Navy of eastern territory. One of its functions is setting and controlling the plan and program in 
maintenance, which is executed by the ship in the unit comply to planned maintenance system cycle in order to improve technical readiness of the elements comply to the plan and program of KOARMATIM, including maintenance of navigating devices such as navigation radar.

The utilization of navigation radar in a KRI (Indonesian battleship), in KOARMATIM patrol ship unit in particular, is very vital as a long range detecting device in navigation. It is an absolute necessity during an operation; thus the readiness of navigation radar will have great impact on the execution of operational duties of those elements. Frequently, when the elements are about to execute their operational duties, they face problem with their navigation radar readiness, which will affect the whole preparation of the ship. To prevent this condition from happening, an accurate step must be taken to keep the system performance from falling.

Four JRC JMA 5310 navigation radars in the SATROLARMATIM (Eastern Fleet Patrol Unit) in KRI are distributed among four ships, namely KRI Sura-802, KRI Kakap811, KRI Kerapu-812 and KRI Tongkol-813 (see Table 1).

Table 1. Usage of Navigation Radar in SATROLARMATIM

\begin{tabular}{|c|c|c|c|c|c|}
\hline \multirow[t]{3}{*}{ No } & \multirow[t]{3}{*}{ Name of KRI } & \multicolumn{4}{|c|}{ Navigation Radar } \\
\hline & & \multicolumn{2}{|c|}{ Radar I } & \multicolumn{2}{|c|}{ Radar II } \\
\hline & & Type & $\begin{array}{l}\text { Age } \\
\text { (Year) }\end{array}$ & Type & Age (Year) \\
\hline 1 & $\begin{array}{lll}\text { KRI } & \text { Pandrong } & - \\
801 & & \end{array}$ & JRC JMA 5322-7 & 2 & JRC JMA 5320 & 3 \\
\hline 2 & KRI Sura - 802 & $\begin{array}{l}\text { Sperry Marine V } \\
\text { Master }\end{array}$ & 3 & JRC JMA 5310 & 8 \\
\hline 3 & KRI Kakap - 811 & JRC JMA 5322-7 & 2 & JRC JMA 5310 & 7 \\
\hline 4 & KRI Kerapu - 812 & JRC JMA 5322-7 & 3 & JRC JMA 5310 & 7 \\
\hline 5 & KRI Tongkol -813 & JRC JMA 5322-7 & 2 & JRC JMA 5310 & 8 \\
\hline 6 & KRI Badau - 841 & $\begin{array}{l}\text { KH Manta Digital } \\
1007\end{array}$ & 3 & JRC JMA 2343 & 3 \\
\hline 7 & $\begin{array}{lll}\text { KRI } & \text { Salawaku } & - \\
842 & & \\
\end{array}$ & $\begin{array}{l}\text { KH Manta Digital } \\
1007\end{array}$ & 3 & JRC JMA 2343 & 3 \\
\hline 8 & KRI Pari - 849 & $\begin{array}{l}\text { Sperry Marine V } \\
\text { Master }\end{array}$ & 2 & JRC JMA 2300 & 2 \\
\hline 9 & KRI Sidat -851 & $\begin{array}{l}\text { Sperry Marine V } \\
\text { Master }\end{array}$ & 1 & JRC JMA 2300 & 1 \\
\hline
\end{tabular}

These four navigation radars have reached 7.5 years of usage with more than 10,000 operating hours, which urges more frequent inspection of their technical condition. O'Connor (2001) defines inspection as an action aiming at avoiding the system from sudden breakdown and discovering whether it works well in compliance with its function.

Judging from the condition of the JRC JMA 5310 Radar onboard KRI SATROLARMATIM, it is essential to have a correct maintenance plan for repair priorities, whether for avoiding various kinds of failure or to predict and discover an easy way to avoid failure. It is not an easy task to define the correct step to avoid failure. This step combines technical requirements with management strategy [1,2]. The transpired component failure is studied to discover the solution that must be taken, complying with the form of failure and the effect and cost to the entire system. Information data of the failure helps personnel in defining the correct repair and different priorities for every failed component.

Herry in [3] proposes application of Fuzzy and TOPSIS method of FMEA to define critical component and repair priorities of various selected alternatives for component failures applied to Sperry Marine Navigation Radar system with the expectation of improving the ship operational performance by applying this method. The research does 
not consider setting of time interval for changing critical component and the optimum cost for maintenance. Budget often becomes the cause for a more technical order manual oriented maintenance so far, and less consideration of expiration date of a component, or in other word, while it lasts, a component will still be used. Therefore, in its turn will end in high penalty cost if continuously applied and causes high budget.

This research proposes Failure Mode Effects and Criticality Analysis (FMECA) model in setting time interval for changing critical components of JRC JMA 5310 Navigation Radar with the consideration of optimizing maintenance cost in improving its reliability value [4-11]. Rausand [12] and Hoyland and Raussand [13] clarify FMECA as a methodology to identify and analyze all modes of potential failure of various parts of the system, the effect of this failure to the system, how to avoid failure and or eliminate the impact of the failure to the system.

The rest of this paper is organized as follow: Section 2 describes the theoretical background. Section 3 describes the proposed method. Section 4 describes obtained results and following by discussion. Finally, section 5 concludes this work.

\section{Theoretical Background}

\subsection{Radio Detection and Ranging}

Eaves (1987) [14] clarifies that the term radar derives from a code used by the United States Navy in 1940 during the World War II, which is the shortened of radio detection and ranging. It is an active long range detecting system, providing its own illumination source. Radio wave is transmitted as a high energy pulse from microwave energy. The pulse interacts with atmosphere and target. The portion of the energy is retransmitted, received by the target and then the intensity and delay time between transmission and returning signal is measured. Radar signal is displayed in Plan Position Indicator (PPI) or other radar system display. A PPI has a rotation vector with radar at the source, which identifies the direction of antenna and target initial degree.

Since its initial discovery by Sir Robert Watson Watt i.e. the Father of Radar in 1932, radar has gone through rapid development in its technology [15]. The development is aimed at improving the effectiveness of its usage and adding efficiency to its application and maintenance and improving reliability of its system. As an illustration, the first Radar can only pick up a target and show the sector of the target location (See Figure 1). Modern generation Radar can pick up target by determining the target coordinate, height, distance, speed, and other benefitting information accurately. In the era of globalization, the role and function of Radar in daily life is vital, indicated from the urgency of the life of civil society and military interest supported by Radar devices.

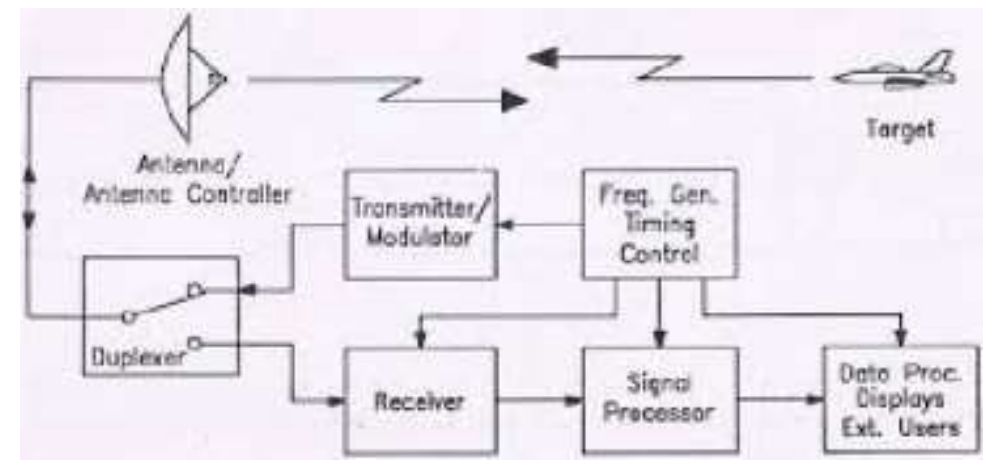

Figure 1. Block Diagram of Radar Working Principle [16] 


\subsection{Failure Modes Effects and Criticality Analysis (FMECA)}

The FMECA [17-19] is initially developed by National Aeronautics and Space Administration (NASA) with the intention of improving and verifying the reliability of the Hardware of MIL-STD-785 space program entitled Reliability Program for System and Equipment Development and Production which specifies the procedure for applying FMECA on devices or system. Meanwhile, MIL-STD-1629 is a military standard that sets requirements and procedures for executing FMECA to evaluate and document potential impact of each functional or hardware failure to the success of mission, safety of personnel and system, and maintenance and performance of the system. Rausand [12] defines FMECA as a methodology in identifying and analyzing:

a. All modes of potential failure of various parts of the system

b. The effect of the failure to the system

c. How to avoid failure or eliminating the impact of failure to the system.

The procedure for Failure Modes Effects and Criticality Analysis (FMECA) in the outline can include several systematic steps [20,21], namely:

a. Identifying all potential failure modes and their causes.

b. Evaluating the effect of each failure modes in the system.

c. Identifying method in detecting broke down/failure.

d. Identifying corrective measure for failure modes.

e. Accessing frequency and urgency level of important failure for critical analysis which is applicable.

Meanwhile, Zafiropoulos and Dialynas [22] propose basic steps in conventional FMECA, namely:

a. Defining system, including identification of internal and interface function, expected performance in various levels of complexity, system restriction, and definition of failure.

b. Conducting functional analysis which illustrates related operation activity and functional entity dependence.

c. Identifying failure mode and its effect, all potential failure modes of identified item and interface and its impact to direct function, item and system must be clearly defined.

d. Setting severity rating $(\mathrm{S})$ of failure mode which refers to the seriousness of effect of failure mode.

e. Setting occurrence rating $(\mathrm{O})$ of the frequency of failure mode occurrence and analyzing failure mode criticality. With the assumption that system components are inclined to fail in various ways, this information is used to picture the most critical aspect of system design.

f. Setting Detection Rating (D) of design control criteria of failure mode occurrence.

g. Setting Risk Priority Number (RPN) which is the result of multiplication of Severity, Occurrence and Detection weights. This result can define critical component.

$$
R P N=\text { Severity }(\mathrm{S}) \times \text { Occurrence }(\mathrm{O}) \times \text { Detection }(\mathrm{D})
$$

Some experts believe that $\mathrm{S}, \mathrm{O}$ and $\mathrm{D}$ factors are not easy to be evaluated accurately. The evaluation attempt is conducted linguistically [23] (See Tables 2, 3 and 4). 
Table 2. Severity Index

\begin{tabular}{|c|c|c|}
\hline Rating & Effect & Severity Effect \\
\hline 10 & Hazardous without warning (HWOW) & $\begin{array}{l}\text { Very high level of exploit when potential failure mode affect } \\
\text { system safety without warning }\end{array}$ \\
\hline 9 & Hazardous with warning (HWW) & $\begin{array}{l}\text { Very high level of exploit when potential failure mode affect } \\
\text { system safety with a warning }\end{array}$ \\
\hline 8 & Very High (VH) & $\begin{array}{l}\text { System is dysfunctional, failure causing breakdown/failure } \\
\text { without safety damage }\end{array}$ \\
\hline 7 & $\operatorname{High}(\mathrm{H})$ & System cannot operate, with damage to device \\
\hline 6 & Moderate (M) & System cannot operate, with moderate failure \\
\hline 5 & Low (L) & System cannot operate, without failure \\
\hline 4 & Very Low (VL) & System can operate, with significant drop of performance \\
\hline 3 & Minor (MR) & System can operate, with some drops of performance \\
\hline 2 & Very Minor (VMR) & System can operate, with minor interruption \\
\hline 1 & None $(\mathrm{N})$ & No effect \\
\hline
\end{tabular}

Table 3. Occurrence Index

\begin{tabular}{|c|c|c|}
\hline Rating & Probability of occurrence & Failure probability \\
\hline 10 & $\begin{array}{l}\text { Very High }(\mathrm{VH}) \text { : Failure } \\
\text { almost unavoidable }\end{array}$ & $>1$ in 2 \\
\hline 9 & & 1 in 3 \\
\hline 8 & High $(\mathrm{H})$ : Repeated failure & 1 in 8 \\
\hline 7 & & 1 in 20 \\
\hline 6 & & 1 in 80 \\
\hline 5 & Moderate (M) : Occasional & 1 in 400 \\
\hline 4 & failure & 1 in 8000 \\
\hline 3 & & 1 in 15000 \\
\hline 2 & Low (L) : Relatively low & 1 in 150000 \\
\hline 1 & failure & $<1$ in 150000 \\
\hline
\end{tabular}

Table 4. Detection Index

\begin{tabular}{|c|c|c|}
\hline Rating & Detection & Probability of Detection by controller \\
\hline 10 & Absolute Uncertainly(AU) & Controller cannot detect the cause of failure and next failure mode. \\
\hline 9 & Very remote (VR) & $\begin{array}{l}\text { Very remote capacity of controller to detect cause of failure and next } \\
\text { failure mode. }\end{array}$ \\
\hline 8 & Remote (R) & $\begin{array}{l}\text { Remote capacity of controller to detect cause of failure and next } \\
\text { failure mode. }\end{array}$ \\
\hline 7 & Very Low (VL) & $\begin{array}{l}\text { Very low capacity of controller to detect cause of failure and next } \\
\text { failure mode. }\end{array}$ \\
\hline 6 & Low (L) & $\begin{array}{l}\text { Low capacity of controller to detect cause of failure and next failure } \\
\text { mode. }\end{array}$ \\
\hline 5 & Moderate (M) & $\begin{array}{l}\text { Moderate capacity of controller to detect cause of failure and next } \\
\text { failure mode. }\end{array}$ \\
\hline 4 & Moderately High (MH) & $\begin{array}{l}\text { Moderately high capacity of controller to detect cause of failure and } \\
\text { next failure mode. }\end{array}$ \\
\hline 3 & High $(\mathrm{H})$ & $\begin{array}{l}\text { High capacity of controller to detect cause of failure and next failure } \\
\text { mode. }\end{array}$ \\
\hline
\end{tabular}




\begin{tabular}{|c|l|l|}
\hline 2 & Very High (VH) & $\begin{array}{l}\text { Very high capacity of controller to detect cause of failure and next } \\
\text { failure mode. } \\
\text { Almost certain capacity of controller to detect cause of failure and } \\
\text { next failure mode. }\end{array}$ \\
\hline
\end{tabular}

\subsection{Probability Distributions}

\subsubsection{Weibull Distribution}

Weibull distribution has been used widely in reliability analysis, mainly in measuring components' life. This form of distribution is also one of the distributions most often used in reliability engineering field since it has the capacity to model different and high number of data with $\beta$ shape parameter value setting. Jardine in [24] believes that Weibull Distribution can be presented in two or three forms of parameter. The PDF function of the three parameter of Weibull Distribution is stated as:

$$
\operatorname{MRL}(t)=\frac{1}{R(t)}\left[\operatorname{MTTF}-\int_{0}^{t} R(t) d t\right]
$$

where $\beta=$ form parameter, $\beta>0, \eta=$ scale parameter, $\eta>0$, and $\gamma=$ location parameter, $\gamma<$ time of first failure. Reliability function of Weibull distribution can be stated as:

$$
f(t)=\frac{\beta}{\eta}\left(\frac{t-\gamma}{\eta}\right)^{\beta-1} e^{-\left(\frac{t-\gamma}{\eta}\right)^{\beta}}
$$

Reliability function of Weibull distribution can be stated as:

$$
R(t)=e^{-\left(\frac{t-\gamma}{\eta}\right)^{\beta}}
$$

Failure rate can be stated as:

$$
\lambda(t)=\frac{\beta}{\eta}\left(\frac{t-\gamma}{\eta}\right)^{\beta-1}
$$

If $\gamma=0$, then Weibull distribution has two parameter. If $\beta>1$, then PDF at $t=\gamma$ the size of PDF equals to zero, similarly failure rate equals to zero. Hence, according to equation (1) for PDF, equation (2) for $R(t)$ and equation (3) for $\lambda(t)$, the reliability value $R(t)=1$. The bigger value of a component $\eta$, the smaller the probability of failure of the component (Refer to equation (4). If the $\eta$ value of component $A$ bigger than component $B$, then the faster reliability value of component $B$ drop compare to component $A$. 


\subsubsection{Exponential Distribution}

Exponential distribution is widely used in reliability engineering since this distribution can represent distribution of failure time of a component/system phenomenon. Alkaff in [25] founds that compact function of exponential distribution can be stated in the following equation:

$$
f(t)=\lambda e^{-\lambda t} ; \mathrm{t}>0, \lambda>0 .
$$

The cumulative distribution function is given as:

$$
F(t)=1-e^{-\lambda t}
$$

where $t=$ time and $\lambda=$ constant failure rate. Thus, the reliability function is given as:

$$
R(t)=1-F(t)=e^{-\lambda t} .
$$

Failure rate is given as:

$$
\begin{aligned}
& \lambda(t)=\frac{f(T)}{\mathrm{R}(t)}=\lambda \\
& M T T F=\int_{0}^{\infty} R(t) d t=\frac{1}{\lambda} .
\end{aligned}
$$

\subsubsection{Normal Distribution}

Jardine [24] finds that normal distribution (Gaussian) is useful in depicting the effect of added time when it can specify time between failures in relation to uncertainties; normal distribution has the following formula:

$$
f(t)=\frac{1}{\sigma \sqrt{2 \pi}} \exp \left[\frac{-(t-\mu)^{2}}{2 \sigma^{2}}\right], \text { for }-\infty \leq t \leq \infty,
$$

where $\sigma$ is the standard deviation of $T$ random variable and $\mu$ is the means of $T$ random variable. Therefore, the cumulative distribution function is given as:

$$
F(t)=\frac{1}{\sigma \sqrt{2 \pi}} \exp \left[\frac{-(t-\mu)^{2}}{2 \sigma^{2}}\right] d t
$$

Reliability function of normal distribution is given as:

$$
R(t)=\int_{t}^{\infty} \frac{1}{\sigma \sqrt{2 \pi}} \exp \left[\frac{-(t-\mu)^{2}}{2 \sigma^{2}}\right] d t
$$

Failure rate of normal distribution can be collected by using the equation as follow: 


\section{Research Method}

$$
\lambda(t)=\frac{\exp \left[-(t-\mu)^{2} / 2 \sigma^{2}\right]}{\int_{t}^{\infty} \exp \left[-(t-\mu)^{2} / 2 \sigma^{2}\right] d t}
$$

\subsection{FMECA Model in Setting Critical Components}

The steps of Failure Mode Effects and Criticality Analysis (FMECA) model clarified complying with flowchart of the research, are as follows:

a. Identifying JRC JMA 5310 Radar system, including identification of internal and interface function, performance expected in various levels of complexity, system restriction, and definition of failure.

b. Identifying potential failure mode, all potential failure modes of item and interface are identified, and their effects to direct function, item and system must be clearly defined.

c. Setting severity rating (S) of failure mode, referring to the seriousness of the impact or effect of failure mode.

d. Setting occurrence rating $(\mathrm{O})$ of the frequency of failure mode and analysis of failure mode criticality. With the assumption that system component is inclined to suffer failure in various ways, this information is used to picture the most critical aspect of system design.

e. Setting detection rating (D) of design control criteria of failure mode.

f. Calculating Risk Priority Number (RPN) to identify setting of critical component of JRC JMA 5310 Radar.

$$
R P N=\text { Severity }(\mathrm{S}) \times \text { Occurrence }(\mathrm{O}) \times \text { Detection }(\mathrm{D})
$$

g. Cumulative results of components with the highest RPN value are selected as candidate for critical component.

\subsection{Risk Matrix}

The next step is conducting analysis of criticality of components using risk matrix complying with the set criteria. The end results are items included in "high" rating of risk based on risk matrix. All the results of FMECA model and risk matrix analysis will be presented in FMECA Worksheet form. Tables 5, 6, 7 and 8 show the categories of failure based on their impact level to the system or personnel.

Table 5. Severity of Consequences

\begin{tabular}{|l|l|}
\hline \multicolumn{1}{|c|}{ Category } & \multicolumn{1}{c|}{ Severity of Consequences } \\
\hline Catastrophic (I) & Causing system shutdown \\
\hline Critical (II) & System cannot function as set \\
\hline Marginal (III) & System has performance function drop \\
\hline Negligible (IV) & System can function with minimum risk \\
\hline
\end{tabular}


Table 6. Severity of Frequency

\begin{tabular}{|c|c|c|}
\hline \multicolumn{3}{|c|}{ Severity of Frequency } \\
\hline \multirow{2}{*}{$\begin{array}{l}\text { Occurrence } \\
\text { Frequency }\end{array}$} & \multicolumn{2}{|l|}{ Definition } \\
\hline & Qualitative & Quantitative \\
\hline Frequent & Often Happen & $\geq 1 \times 10^{-3}$ hours \\
\hline Probable & High Probability of Happening & $\geq 1 \times 10^{-4}$ hours \\
\hline Occasional & Occasionally Happen & $\geq 1 \times 10^{-5}$ hours \\
\hline Remote & Remotely Happen & $\geq 1 \times 10^{-6}$ hours \\
\hline Improbable & Improbable to Happen & $<1 \times 10^{-7}$ hours \\
\hline
\end{tabular}

Table 7. Risk Matrix

\begin{tabular}{|c|c|c|c|c|c|}
\hline Frequency & Frequent & Probable & Occasional & Remote & Improbable \\
\hline $\begin{array}{c}\text { Catastrophic } \\
\text { (I) }\end{array}$ & 1 & 2 & 4 & 8 & 12 \\
\cline { 2 - 6 } & High & High & High & Moderate & Moderate \\
\hline $\begin{array}{c}\text { Critical } \\
(\text { II) }\end{array}$ & 3 & 5 & 6 & 10 & 15 \\
\cline { 2 - 6 } $\begin{array}{c}\text { Marginal } \\
(\text { III) }\end{array}$ & High & High & Moderate & Acceptable & Acceptable \\
\cline { 2 - 6 } & Moderate & Moderate & Acceptable & Acceptable & Acceptable \\
\hline \multirow{2}{*}{$\begin{array}{c}\text { Negligible } \\
(\text { IV) }\end{array}$} & 13 & 16 & 18 & 19 & 20 \\
\cline { 2 - 6 } & Acceptable & Acceptable & Acceptable & Acceptable & Acceptable \\
\hline
\end{tabular}

Table 8. Rating of Risk

\begin{tabular}{|l|l|}
\hline \multicolumn{1}{|c|}{ Rating } & \multicolumn{1}{c|}{ Definition } \\
\hline High & Need repair to eliminate danger \\
\hline Medium & Need review of risk acceptability \\
\hline Acceptable & Acceptable risk reviewed as ripe design \\
\hline
\end{tabular}

\subsection{Model for Setting Time Interval for Changing Critical Component}

From the data of reliability and MBTF values collected, optimum interval for component changing can be set using excel program. Flowchart of change time interval calculation can be seen in Figure 2. 


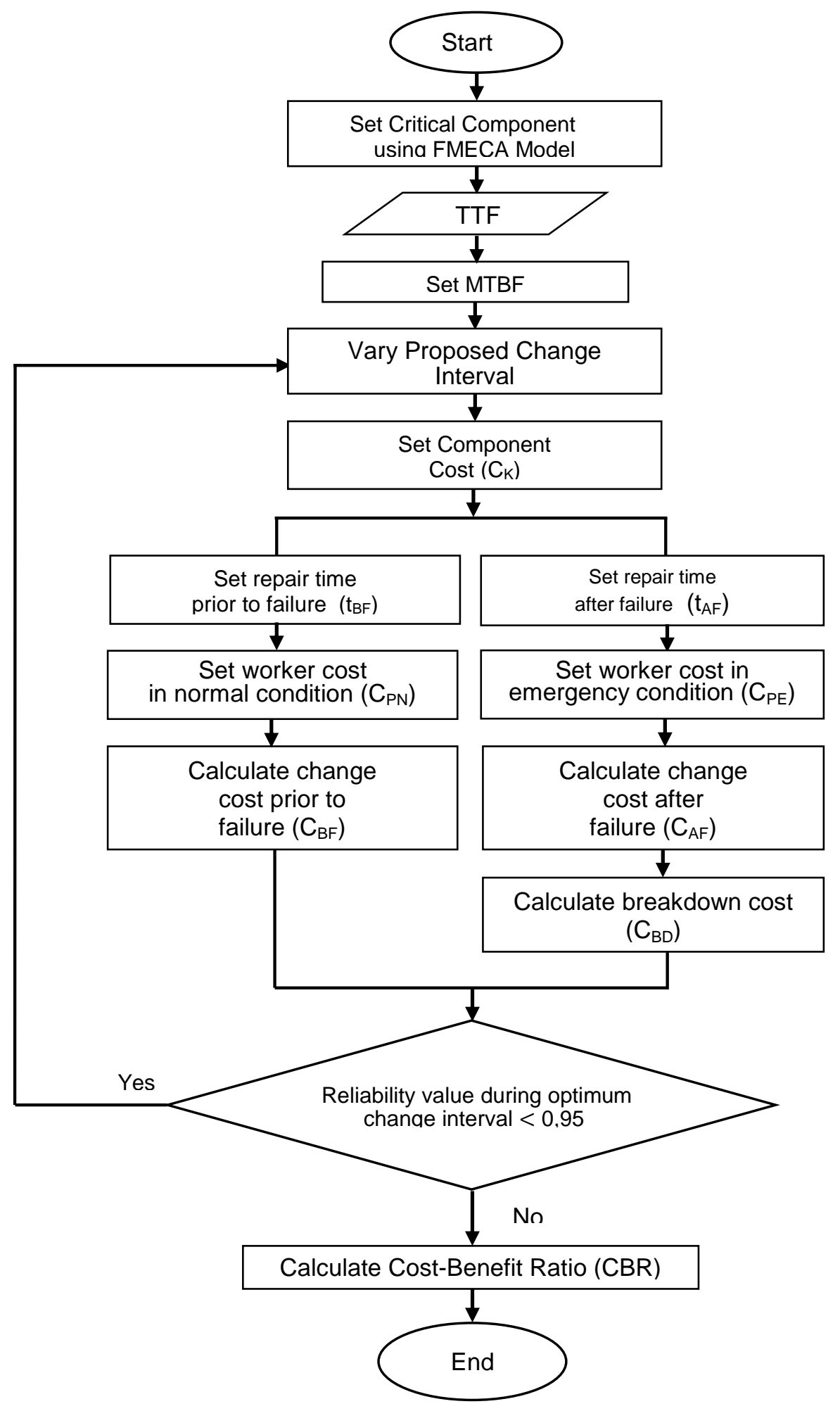

Figure 2. Flowchart of Setting Model of Time Interval for Critical Component Change 


\subsection{Cost Benefit Ratio (CBR) Model for Component Changing}

Cost Benefit Ratio (CBR) lower than $1(\mathrm{CBR}<1)$ means the activity is beneficial, or in other word Benefit should be greater than Cost. As an illustration, when change is conducted prior to failure, the benefit collected will be maximum and cost can be pressed, which is of course beneficial. To generate change cost for each component, Satria in [26] proposes the following equation:

$$
C B R=\frac{R_{(T)} \cdot\left[C_{K}+\left(t_{B F} \cdot C_{P N}\right)\right]+\left[\left(1-R_{(T)}\right) \cdot\left\{C_{K}+\left(t_{A F} \cdot C_{P E}\right)+\left(t_{A F} \cdot C_{B D}\right)\right\}\right]}{C_{K}+\left(t_{A F} \cdot C_{P E}\right)+\left(t_{A F} \cdot C_{B D}\right)}
$$

where:

CBR : Cost Benefit Ratio

$\mathrm{C}_{\mathrm{K}} \quad$ : Component cost

$\mathrm{R}_{(\mathrm{T})} \quad$ : Reliability

$1-R_{(T)}:$ Probability of failure

$\mathrm{t}_{\mathrm{BF}} \quad$ : Repair time prior to failure

$\mathrm{t}_{\mathrm{AF}} \quad$ : Repair time after failure

$\mathrm{C}_{\mathrm{PN}} \quad:$ Worker cost in normal/planned condition

$\mathrm{C}_{\mathrm{PE}} \quad$ : Worker cost in emergency condition

$\mathrm{C}_{\mathrm{BD}} \quad$ : Cost during breakdown

\section{Data Collecting and Processing}

\subsection{FMECA Questionnaire Result Data Calculation}

Questionnaire data is collected employing a selected concept unseparated from FMECA terminology containing identification of component failure mode and identification of risk assessment criteria of component failure mode. Expert sources for this questionnaire are Head of Electronic Workshop of Fasharkan Lantamal V, Kasihar Sewaco Satrolarmatim [27], Head of Electronic Department of KRI Sura-802 and Technical Director of PT Jala Purangga Sena. Furthermore, data resulted from questionnaire is extracted to collect the severity, occurrence and detection rating of each component collected by the experts. From these values of severity, occurrence, and detection, RPN value of the component can be calculated. The RPN values of all components are then sorted from highest to lowest to produce ranking/priority of component criticality level. Recapitulation and ranking of RPN value calculation results is presented in Table 9 below:

Table 9. Risk Priority Number (RPN) Value

\begin{tabular}{|c|l|c|c|}
\hline No & \multicolumn{1}{|c|}{ Component } & RPN & Ranking \\
\hline 1 & Modulator (K1) & 24180 & 1 \\
\hline 2 & Power Supply Scanner (K9) & 23040 & 2 \\
\hline 3 & Diode Limiter (K8) & 20280 & 3 \\
\hline 4 & Magnetron (K6) & 16800 & 4 \\
\hline 5 & Receiver (K2) & 15950 & 5 \\
\hline 6 & Motor (K3) & 13500 & 6 \\
\hline 7 & Radar Processor (K10) & 11648 & 7 \\
\hline 8 & Circulator (K7) & 11220 & 8 \\
\hline 9 & Rotary Joint (K4) & 8602 & 9 \\
\hline
\end{tabular}




\begin{tabular}{|l|l|l|l|}
\hline 10 & Track Ball (K22) & 7524 & 10 \\
\hline 11 & Power Supply CPU (K18) & 7500 & 11 \\
\hline 12 & Transformer (K23) & 7475 & 12 \\
\hline 13 & Monitor Fan (K20) & 7452 & 13 \\
\hline 14 & Bridge Diode (K24) & 7140 & 14 \\
\hline 15 & Keyboard Matrix (K21) & 7106 & 15 \\
\hline 16 & Condensate (K25) & 6804 & 16 \\
\hline 17 & Radiator / Antenna (K5) & 6336 & 17 \\
\hline 18 & LCD Monitor (K19) & 6072 & 18 \\
\hline 19 & I/F Chassis (K16) & 5750 & 19 \\
\hline 20 & Filter (K26) & 5187 & 20 \\
\hline 21 & Terminal Board (K12) & 4840 & 21 \\
\hline 22 & NSK Circuit (K13) & 4620 & 22 \\
\hline 23 & ARPA (K11) & 4488 & 23 \\
\hline 24 & I/O Circuit (K15) & 4095 & 24 \\
\hline 25 & AIS Interface (K17) & 3822 & 25 \\
\hline 26 & UPS (K27) & 3640 & 26 \\
\hline 27 & Plotter Control Circuit (K14) & 3289 & 27 \\
\hline
\end{tabular}

\subsection{Setting Critical Components}

The data collected from the analysis of severity of consequence and severity of frequency of each component above are then processed in risk matrix to clarify component rating of risk complying with the criteria set in Table 10 with the combination of failure consequence level and potential occurrence frequency level. Components regarded as "catastrophic" or "critical" in severity of consequence are not necessarily included in the classification of critical component intended here. In a similar way, component with very high failure frequency (probable) cannot be surely included in critical component category. Critical components intended in this paper are component with "high" rating of risk category based on the result of analysis in FMECA method. This is due to the higher mean of occurrence frequency level and failure impact seriousness level of the components with high risk level compared to other components classified in "moderate" and "acceptable" rating of risk category. The results of risk matrix analysis of each component are presented in Table 10 below.

Table 10. Component Rating of Risk

\begin{tabular}{|c|l|c|}
\hline No & \multicolumn{1}{|c|}{ Component } & Rating of Risk \\
\hline 1 & Modulator (K1) & High \\
\hline 2 & Power Supply Scanner (K9) & High \\
\hline 3 & Diode Limiter (K8) & High \\
\hline 4 & Magnetron (K6) & High \\
\hline 5 & Receiver (K2) & High \\
\hline 6 & Motor (K3) & High \\
\hline 7 & Radar Processor (K10) & Moderate \\
\hline 8 & Circulator (K7) & High \\
\hline 9 & Rotary Joint (K4) & Acceptable \\
\hline 10 & Track Ball (K22) & Acceptable \\
\hline 11 & Power Supply CPU (K18) & Acceptable \\
\hline 12 & Transformer (K23) & Acceptable \\
\hline 13 & Monitor Fan (K20) & Acceptable \\
\hline 14 & Bridge Diode (K24) & Acceptable \\
\hline 15 & Keyboard Matrix (K21) & Acceptable \\
\hline
\end{tabular}




\begin{tabular}{|l|l|l|}
\hline 16 & condensate (K25) & Acceptable \\
\hline 17 & Radiator / Antenna (K5) & Acceptable \\
\hline 18 & LCD Monitor (K19) & Acceptable \\
\hline 19 & I/F Chassis (K16) & Acceptable \\
\hline 20 & Filter (K26) & Acceptable \\
\hline 21 & Terminal Board (K12) & Acceptable \\
\hline 22 & NSK Circuit (K13) & Acceptable \\
\hline 23 & ARPA (K11) & Acceptable \\
\hline 24 & I/O Circuit (K15) & Acceptable \\
\hline 25 & AIS Interface (K17) & Acceptable \\
\hline 26 & UPS (K27) & Acceptable \\
\hline 27 & $\begin{array}{l}\text { Plotter Control Circuit } \\
\text { (K14) }\end{array}$ & Acceptable \\
\hline
\end{tabular}

Critical component with high risk and RPN out of the 27 components analyzed based on rating of risk can be seen in Table 11 below:

Table 11. Critical Component

\begin{tabular}{|c|l|l|l|c|c|}
\hline No & \multicolumn{1}{|c|}{ Component } & \multicolumn{2}{|c|}{ Category } & Risk Matrix & RPN \\
\hline 1 & Modulator & Critical & Probable & High & 24180 \\
\hline 2 & Power Supply Scanner & Catastrophic & Probable & High & 23040 \\
\hline 3 & Diode Limiter & Critical & Probable & High & 20280 \\
\hline 4 & Magnetron & Critical & Probable & High & 16800 \\
\hline 5 & Receiver & Catastrophic & Occasional & High & 15950 \\
\hline 6 & Motor & Catastrophic & Occasional & High & 13500 \\
\hline 7 & Circulator & Critical & Probable & High & 11220 \\
\hline
\end{tabular}

\section{Result and Discussion}

\subsection{Analysis of Reliability Value Prior to Interval Changing}

Prior to calculation of time interval for component change to adjust reliability value to what expected, calculation of reliability value prior to change is conducted (See Table 12).

Table 12. Value of Component Reliability Prior to Change

\begin{tabular}{|c|l|c|c|}
\hline No & \multicolumn{1}{|c|}{ Component } & MTBF (Day) & Reliability \\
\hline 1 & Modulator & 274 & 0.537901 \\
\hline 2 & Power Supply Scanner & 273 & 0.551594 \\
\hline 3 & Diode Limiter & 162 & 0.486821 \\
\hline 4 & Magnetron & 177 & 0.482604 \\
\hline 5 & Receiver & 166 & 0.499164 \\
\hline 6 & Motor & 464 & 0.442824 \\
\hline 7 & Circulator & 463 & 0.433815 \\
\hline
\end{tabular}

The results of the calculation presented in Table 12 above show that power supply scanner component has a high reliability value of 0.551594 which does not meet the target, namely above 0.95 in accordance to minimum setting of instrumentation part. Meanwhile, component with the lowest reliability value is circulator component with 0.433815 . From the component reliability value data above, it can be seen that a correct time interval setting is required so that the reliability value of the component can be improved as intended. 


\subsection{Analysis of Reliability Value after Interval Changing}

After calculation of changing time interval setting is conducted, new reliability value is collected. This calculation inserts variation of changing time interval and is calculated using parameter table of confirmed distribution result (Weibull 3). The reliability minimum limit required for operational of a component is 0.95 . Table 13 below shows the results of calculation of changing time interval setting for critical component.

Table 13. Value of Component Reliability after Change

\begin{tabular}{|c|l|c|c|c|}
\hline No & \multicolumn{1}{|c|}{ Component } & $\begin{array}{c}\text { MTBF } \\
\text { (Day) }\end{array}$ & $\begin{array}{c}\text { Change Time } \\
\text { Interval (Day) }\end{array}$ & Reliability \\
\hline 1 & Modulator & 274 & 234 & 0.953037 \\
\hline 2 & Power Supply Scanner & 273 & 232 & 0.951484 \\
\hline 3 & Diode Limiter & 162 & 152 & 0.958165 \\
\hline 4 & Magnetron & 177 & 157 & 0.957328 \\
\hline 5 & Receiver & 166 & 157 & 0.952719 \\
\hline 6 & Motor & 464 & 458 & 0.980802 \\
\hline 7 & Circulator & 463 & 458 & 0.970894 \\
\hline
\end{tabular}

The result of calculation shown in Table 13 above shows that the reliability level of all components has met the target, namely above 0.95 , which is appropriate to minimum limit of instrumentation part. Diode limiter component has the fastest changing time, namely 152 days, while component with the longest changing time, namely 458 days, are motor and circulator.

\subsection{Analysis of Component Changing Cost}

Previous chapters have discussed the cost for component changing prior to and after failure. The data resulted from the calculation of component changing cost after failure, when applying method for component changing, complying with the time interval proposed/recommended for every critical component, the cost will become beneficial for saving maintenance budget for JRC JMA 5310 Radar.

Perceiving whether critical component changing is effective from cost aspect can be clarified by calculating Cost Benefit Ratio (CBR). Table 5.3 below shows CBR calculation of critical component changing process:

Table 14. Cost Benefit Ratio (CBR)

\begin{tabular}{|c|l|c|c|c|c|}
\hline No & \multicolumn{1}{|c|}{$\begin{array}{c}\text { Component } \\
\text { Name }\end{array}$} & $\begin{array}{c}\text { Time Interval } \\
\text { for Change } \\
\text { (Day) }\end{array}$ & $\begin{array}{c}\text { Total Change } \\
\text { Cost } \\
\text { (IDR) }\end{array}$ & $\begin{array}{c}\text { Benefit When Following } \\
\text { Recommendation } \\
\text { (IDR) }\end{array}$ & CBR \\
\hline 1 & Modulator & 234 & $28,746,431$ & $33,240,000$ & 0.86481 \\
\hline 2 & Power Supply Scanner & 232 & $25,403,755$ & $29,890,000$ & 0.84991 \\
\hline 3 & Diode Limiter & 152 & $4,479,121$ & $7,780,000$ & 0.57572 \\
\hline 4 & Magnetron & 157 & $7,037,051$ & $8,990,000$ & 0.78276 \\
\hline 5 & Receiver & 157 & $24,826,501$ & $27,980,000$ & 0.88729 \\
\hline 6 & Motor & 458 & $29,127,711$ & $34,375,000$ & 0.84735 \\
\hline 7 & Circulator & 458 & $6,196,341$ & $9,410,000$ & 0.65848 \\
\hline
\end{tabular}

Table 14 above elaborates that the result of every critical component changing is effective from cost aspect, such is shown from CBR value of every critical component, namely less than $1(\mathrm{CBR}<1)$. 


\subsection{Sensitivity Analysis}

The $R(t)$ reliability is the variable that can directly affect the setting of time interval for changing critical component, which includes changing time interval $(t p), \beta$ parameter (slope), $Y$ parameter (location), $I$ parameter (scale) variables. Meanwhile, for component cost variable, repair cost and repair time are standard variable with relatively constant values so that the variable does not significantly affect alteration of the model used.

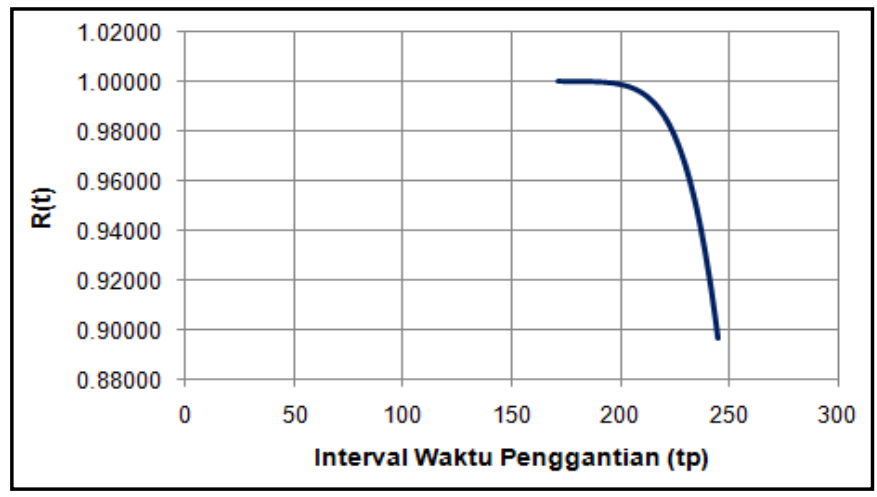

Figure 3. Graphic of Modulator Component tp and $R(t)$ Relation

The result of graphic analysis in Figure 3 above shows that component reliability value will alter in contrast to changing time interval, the higher the change time interval (operational time), the lower the component reliability value.

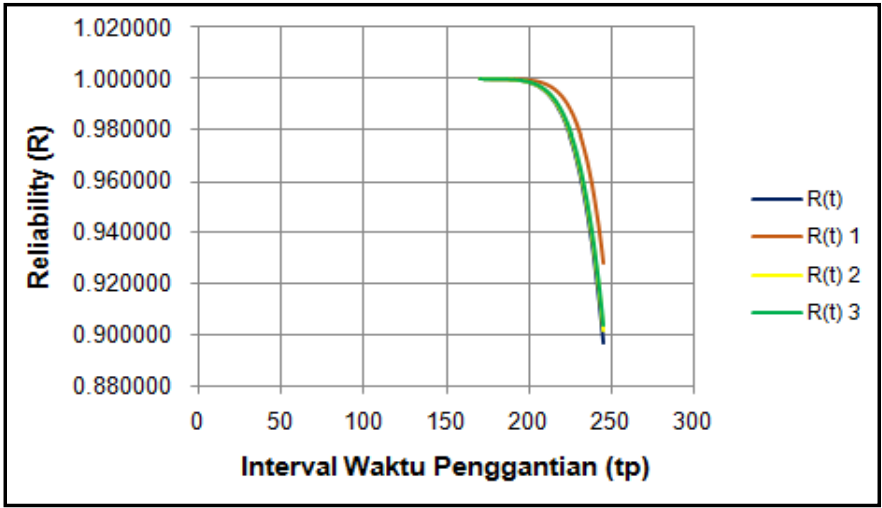

Figure 4. Graphic of Modulator Component $R(t)$ Value Comparison if Parameters $\beta, Y$, and $\eta$ are Increased

Figure 4 above shows graphic for reliability value comparison for modulator component. The $R(t) 1, R(t) 2$ and $R(t) 3$ are Reliability values if $\beta, Y, \eta$ parameter are raised. It can be seen that $R(t) 1$ ascends more significantly compared to $R(t) 2$ and $R(t) 3$, which signifies that $\beta$ parameter has more effect to the alteration of Reliability $R(t)$ value. 


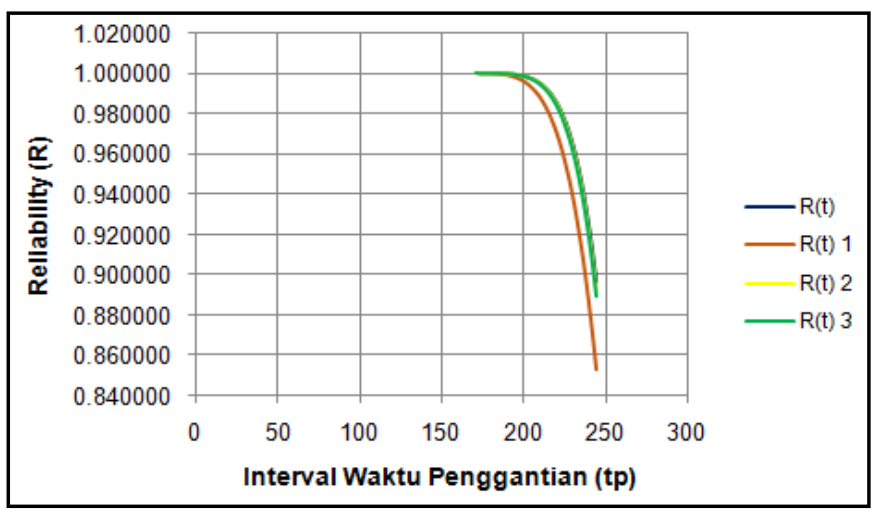

Figure 5. Graphic of modulator component $\boldsymbol{R}(\boldsymbol{t})$ value comparison if parameters $\beta, Y, \eta$ are lowered

Figure 5 above shows the graphic for Reliability value comparison on modulator component when $\beta, Y, \eta$ are lowered. It can be seen that $R(t) 1$ descends more significantly compared to $R(t) 2$ and $R(t) 3$, which also signifies that $\beta$ parameter has more impact to the change of Reliability $R(t)$ value.

\subsection{Discussion}

From the analysis and discussion in previous sections, it can be concluded that:

- Using Failure Mode Effect and Criticality Analysis (FMECA) model, it is found that by calculating Risk Priority Number (RPN) and Risk Matrix of 27 components, 7 components have the highest RPN and Risk Matrix values, namely modulator, power supply scanner, Diode limiter, magnetron, receiver, motor, and circulator components. Modulator component has the highest RPN value of 24180 while Plotter Control Circuit the lowest value of 3289.

- The calculation of time interval setting for changing all critical components generates the result that the fastest component changing time interval is for diode limiter, namely 152 days, while components with the longest changing time interval are motor and circulator components, namely 458 days. The results for other components are as follows, modulator 234 days, power supply scanner 232 days, magnetron and receiver 157 days.

- The result of the analysis shows that component changing cost can be concluded as efficient, where Cost Benefit Ratio (CBR) is less than 1 (CBR < 1). The CBR values of each critical component are as follows: modulator 0.86481, power supply scanner 0.84991, diode limiter 0.57572, magnetron 0.78276, receiver 0.88729, motor 0.84735 and circulator 0.65848 .

- Sensitivity test shows that Reliability $R(t)$ variable has high impact to the change of critical component changing time interval setting, which includes $\beta$ parameter (slope), $Y$ parameter (location), and $I$ parameter (scale).

\section{Conclusion and Suggestion}

This paper has presented an application of FMECA model in defining critical component of JRC JMA 5310 Navigation Radar. The proposed FMECA model generates Risk Priority Number (RPN) that will be used in defining critical components. The obtained RPN value of each component is analyzed using Risk Matrix, which produces seven components regarded as critical out of twenty seven identified components, namely 
Modulator, Power Supply Scanner, Diode Limiter, Magnetron, Receiver, Motor, and Circulator. From the attempts conducted in this research, it is suggested that: (1) There must be a follow up of the research results so that the method for setting time interval for component changing can contribute to the attempt to maintain JRC JMA 5310 Navigation Radar [28]; (2) Maintenance method, in particular for JRC JMA 5310 Navigation Radar, conducted thus far must be evaluated so that its operational readiness can support the main task of the Indonesian Navy, namely guarding the integrity of Indonesian maritime; (3) Journal of failures must be better documented, complying with operational hour to make it easier to set repair priorities to be conducted.

\section{Acknowledgement}

This research is supported by Research Grant from Sekolah Tinggi Teknologi Angkatan Laut, Indonesia.

\section{References}

[1] A. Sachdeva, D. Kumar and P. Kumar, "Multi-Factor Failure Mode Critically Analysis Using TOPSIS", Industrial Engineering International, vol. 5, , (2009), pp. 1-9.

[2] S. Assauri, "Manajemen Produksi dan Operasi, Faculty of Economy Press", Universitas Indonesia, Jakarta, (2004).

[3] A. Herry, "Analisa Penentuan Komponen Kritis dan Rekomendasi Tindakan Pencegahan Keruskan dengan Menggunakan Metode FUZZY FMEA dan TOPSIS", Master Thesis, Sekolah Tinggi Teknologi Angkatan Laut (College of Naval Technology), Surabaya, (2015).

[4] E.E. Lewis, "Introduction to Reliability Engineering 2nd edition", John Wiley and Sons Inc, New York, (1996).

[5] T. P. Omdahl, "Reliability, Availability, and Maintainability (RAM) Dictionar" ASQC quality press, USA, (1988).

[6] P. O'Connor, "Practical Reliability Engineering", Third Edition. John Wiley \& sons limited in Chichester, (2001).

[7] Sematech, "Guidelines for Equipment Reliability", Technology Transfer 92031014A-GEN, (1992).

[8] NAVAIR 00-25-403, "Guidelines for the Naval Aviation Reliability Centered Maintenance Process", Direction of Commander, Naval Air Systems Command, (2003).

[9] S. J. Rhee, "Using Cost Based FMEA to Enhance Reliability and Serviceability", Advanced Engineering Informatics, vol. 17, (2003), pp. 179-188.

[10] D.K. Yanif, "An Investigation Into Application of Maintenance Management Concept Based on Reliability Centered Maintenance of TNI-AL Fleet" Faculty of Marine Engineering, ITS, Surabaya, (2003).

[11] A. K. Govil, "Reliability Engineering”, Tata Mc. Graw Hill Publication, New Delhi, (1983).

[12] M. Rausand, "System Reliability Theory: Models, Statistical Methods and Applications", Departement Productique et Automatique Nantes Cedex 3, France, (2004).

[13] A. Hoyland and M. Raussand, "System Reliability Theory: Models and Statistical Methods", a WileyInterscience Publication, (1994).

[14] J. L. Eaves, "Principles of Modern Radar", Van Nostrand Reinhold Company Inc., New York, (1987).

[15] R.A. Watson-Watt, J.F. Herd and L.H. Bainbridge-Bell, "Applications of the cathode ray oscillograph in radio research", HM Stationery Office, (1933).

[16] M. Kaukab, "Rancang Bangun Simulasi Radar Mobile", Faculty of Engineering, Universitas Indonesia, Jakarta, (2008).

[17] M. Catelani, "Electrical Performances Optimization of Photovoltaic Modules with FMECA Approach", Journal of Measurement, vol. 46, (2013), pp. 3898-3909.

[18] Y. Deng, "A Research on Subway Physical Vulnerability Based on Network Theory and FMECA", Journal of Safety Science, vol. 80, (2015), pp. 127-134.

[19] N.A. Hasbullah and A. Rosmaini, "Failure Analysis of Tyre Production Process Using FMECA Method", School of Manufacturing Engineering, (2016), http://dx.doi.org/10.1016/j.csefa.2015.07.001.

[20] M. Modarres, "Reliability Engineering and Risk Analysis", Marcel Dekker Inc., New York, (1999).

[21] L. Anthony, (2009), "Risk Analysis of Complex and Uncertain Systems", Springer, New York.

[22] E.P. Zafiropoulos and E.N. Dialynas, "Reliability Prediction and Failure Mode Effects and Criticality Analysis of Electronic Devices Using Fuzzy Logic", International Journal of Quality \& Reliability Management, vol. 22, (2005), pp. 183-200.

[23] Y. M. Wang, "Risk Evaluation in Failure Mode and Effects Analysis Using Fuzzy Weighted Geometric Mean", Expert Systems with Applications, vol. 36, (2009), pp. 1195-1207.

[24] A.K.S. Jardine, "Maintenance, Replacement and Reliability", Pitman Publishing, Great Britain, (1973). 
International Journal of Future Generation Communication and Networking Vol.10, No.8 (2017)

[25] A. Alkaff, T. K. Sistem, "Department of Electrical Engineering, Faculty of Industrial Engineering 1TS", Surabaya, (1992).

[26] Y. Satria, "Analisa Penentuan Interval Waktu Penggantian Komponen Kritis pada Alat Instrumentasi QCS Scanner Type 2200-2 di PT Pabrik Kertas Tjiwi Kimia”, MMT ITS, Surabaya, (2012).

[27] Satrolarmatim. Laporan Kondisi Teknis, Komando RI Kawasan Timur, Surabaya, (2015).

[28] Manual Book JRC JMA 5310, Marine Radar Equipment: Instruction Manual JRC JMA 5310, Japan Radio Co. Ltd, Japan. 